\title{
Potensi Metabolik Komunitas Bakteri Endofit dan Rhizosfer Ubi Jalar (Ipomoea batatas L.) Berdasarkan Analisis Community-Level Physiological Profiles (CLPP)
}

\author{
Agustina Tangapo* \\ Jurusan Biologi FMIPA Universitas Sam Ratulangi
}

\begin{tabular}{|c|c|}
\hline KATA KUNCI & A B S T R A K \\
\hline $\begin{array}{l}\text { Komunitas bakteri } \\
\text { CLPP } \\
\text { Ipomoea batatas } \\
\text { Endofit } \\
\text { rhizosfer }\end{array}$ & $\begin{array}{l}\text { Aktivitas metabolik dari komunitas bakteri endofit dan rizosfir diukur untuk } \\
\text { membandingkan tingkat community-level physiological profiling (CLPP) } \\
\text { menggunakan Biolog Ecoplates. Hasil penelitian kami menunjukkan } \\
\text { kepadatan bakteri meningkat dengan urutan: endofit<rhizosfer. Keragaman } \\
\text { mikroba dinilai oleh kekayaan spesies, jumlah spesies dan indeks kesamaan. } \\
\text { Aktivitas total mikroba tertinggi diamati pada mikroba rhizosfer. CLPP } \\
\text { menunjukkan bahwa bakteri bisa memanfaatkan semua kelompok sumber } \\
\text { karbon sebagai berikut karbohidrat, asam amino, asam karboksilat, polimer, } \\
\text { amina/amida, dan senyawa fenolik. Karbohidrat yang paling dimanfaatkan. }\end{array}$ \\
\hline KEYWORDS & A B S T R A C T \\
\hline $\begin{array}{l}\text { Acterial Community } \\
\text { CLPP } \\
\text { Ipomoea batatas } \\
\text { Endophytes } \\
\text { Rhizosphere }\end{array}$ & $\begin{array}{l}\text { Total metabolic activity of endophytic and rhizosphere of bacterial community } \\
\text { of sweet potato was measured to compare the community-level physiological } \\
\text { profiles (CLPP) using by Biolog Ecoplates. Result of our study revealed that } \\
\text { bacterial density increased in the following order: endophytes < rhizosphere. } \\
\text { The microbial diversity assessed by species richness, the total number of } \\
\text { species present and species evenness. The highest total microbial activity } \\
\text { was observed for the rhizosphere. The CLPP revealed that the bacteria could } \\
\text { differentially utilize all the groups of carbon sources as follows carbohydrate, } \\
\text { amino acid, carboxilyc acid, polymer, amine/amide, and phenolic compound. } \\
\text { Carbohydrate was most utilized. }\end{array}$ \\
\hline
\end{tabular}

TERSEDIA ONLINE

01 Februari 2020

Pendahuluan

Dalam komunitas, populasi satu spesies dapat saling berinteraksi dengan spesies lainnya ataupun dengan kondisi fisik dan kimia membangun suatu sistem hidup berdampingan di suatu habitat (Konopka, 2009). Komunitas bakteri dapat berubah secara temporal ataupun spasial. Variasi pada struktur komunitas bakteri dapat mempengaruhi proses-proses pada ekosistem. Analisis communitylevel physiological profiling (CLPP) merupakan pendekatan yang dapat diaplikasikan dalam mempelajari karakteristik dari komunitas bakteri. Metode ini berdasarkan pada penggunaan sumber karbon berbeda oleh bakteri. Pendekatan ini dilakukan dengan inokulasi langsung sampel dari lingkungan ke microplate dan keuntungan dari respons hasilnya dapat menjelaskan perbedaan dalam komunitas bakteri yang tampak dengan perkembangan warna yang menunjukkan variasi dalam diversitas atau pola warna yang terjadi (Garland, 1997). Pendekatan ini mencerminkan aktivitas langsung dan memberikan informasi fisiologis pada pola komunitas dalam pemanfaatan substrat.

Pendekatan metode CLPP menggunakan Biolog EcoPlate yang terdiri dari 96 sumur yang mengandung substrat dan pewarna tetrazolium violet. Pewarna ini akan tereduksi selama ada aktivitas respirasi yang akan menyebabkan pembentukan warna. Setiap lubang yang telah diinokulasi dan terjadi pembentukan warna diukur absorbansinya dengan spektrofotometer pada durasi waktu tertentu. Terdapat 31 substrat dan 1 kontrol (air/A1) pada Biolog EcoPlate yang meliputi kelompok karbohidrat, asam amino, amina, asam karboksilat, senyawa fenolik, dan polimer dengan tiga replikasi (Tabel 1). 


\begin{tabular}{|c|c|c|c|c|}
\hline $\begin{array}{l}\text { Baris/ } \\
\text { Kolom } \\
\end{array}$ & 1 & 2 & 3 & 4 \\
\hline$A$ & $\begin{array}{c}\text { A1 } \\
\text { Water }\end{array}$ & $\begin{array}{l}\text { A2 } \\
\text { B-Methyl-D- } \\
\text { Glucoside }\end{array}$ & $\begin{array}{l}\text { A3 } \\
\text { D-Galactonic } \\
\text { Acid y-Lactone }\end{array}$ & $\begin{array}{l}\text { A4 } \\
\text { L- } \\
\text { Arginine }\end{array}$ \\
\hline B & $\begin{array}{c}\text { B1 } \\
\text { Pyruvic } \\
\text { Acid } \\
\text { Methyl } \\
\text { Ester }\end{array}$ & $\begin{array}{l}\text { B2 } \\
\text { D-Xylose }\end{array}$ & $\begin{array}{l}\text { B3 } \\
\text { D-Galacturonic } \\
\text { Acid }\end{array}$ & $\begin{array}{l}\text { B4 } \\
\text { L- } \\
\text { Asparagi } \\
\text { ne }\end{array}$ \\
\hline C & $\begin{array}{c}\text { C1 } \\
\text { Tween } 40\end{array}$ & $\begin{array}{l}\text { C2 } \\
\text { i-Erythritol }\end{array}$ & $\begin{array}{l}\text { C3 } \\
\text { 2-Hydroxy } \\
\text { Benzoic Acid }\end{array}$ & $\begin{array}{l}\text { C4 } \\
\text { L- } \\
\text { Phenylal } \\
\text { anine }\end{array}$ \\
\hline D & $\begin{array}{c}\text { D1 } \\
\text { Tween } 80\end{array}$ & $\begin{array}{l}\text { D2 } \\
\text { D-Mannitol }\end{array}$ & $\begin{array}{l}\text { D3 } \\
\text { 4-Hydroxy } \\
\text { Benzoic Acid }\end{array}$ & $\begin{array}{l}\text { D4 } \\
\text { L-Serine }\end{array}$ \\
\hline$E$ & $\begin{array}{c}\text { E1 } \\
\alpha- \\
\text { Cyclodextri } \\
n\end{array}$ & $\begin{array}{l}\text { E2 } \\
\text { N-Acetyl-D- } \\
\text { Glucosamine }\end{array}$ & $\begin{array}{l}\text { E3 } \\
\text { Y-Hydroxybutyric } \\
\text { Acid }\end{array}$ & $\begin{array}{l}\text { E4 } \\
\text { L- } \\
\text { Threonin } \\
\text { e }\end{array}$ \\
\hline $\mathrm{G}$ & $\begin{array}{c}\text { F1 } \\
\text { Glycogen }\end{array}$ & \begin{tabular}{|l} 
F2 \\
D- \\
Glucosamini \\
c Acid \\
\end{tabular} & $\begin{array}{l}\text { F3 } \\
\text { Itaconic Acid }\end{array}$ & $\begin{array}{l}\text { F4 } \\
\text { Glycyl-L- } \\
\text { Glutamic } \\
\text { Acid } \\
\end{array}$ \\
\hline $\mathrm{H}$ & $\begin{array}{c}\text { G1 } \\
\text { D- } \\
\text { Cellobiose }\end{array}$ & $\begin{array}{l}\text { G2 } \\
\text { Glucose-1- } \\
\text { Phosphate }\end{array}$ & $\begin{array}{l}\text { G3 } \\
\alpha-\text { Ketobutyric } \\
\text { Acid }\end{array}$ & $\begin{array}{l}\text { G4 } \\
\text { Phenylet } \\
\text { hyl- } \\
\text { amine }\end{array}$ \\
\hline I & $\begin{array}{c}\text { H1 } \\
\alpha-D- \\
\text { Lactose }\end{array}$ & $\begin{array}{l}\text { H2 } \\
\text { D,L- } \alpha- \\
\text { Glycerol } \\
\text { Phosphate }\end{array}$ & $\begin{array}{l}\text { H3 } \\
\text { D-Malic Acid }\end{array}$ & $\begin{array}{l}\mathrm{H} 4 \\
\text { Putresci } \\
\text { ne }\end{array}$ \\
\hline
\end{tabular}

Pendekatan ini sangat berguna untuk karakterisasi diversitas fungsional bakteri dari lingkungan termasuk tanah, air, sedimen, laut dan lumpur aktif. Analisis CLPP sangat bermanfaat dalam mempelajari pola komunitas antar ekosistem yang bervariasi, ekosistem yang sama dengan heterogenitas spasial, maupun dengan variasi temporal. Penelitian Wang et al. (2007) menunjukkan penggunaan Biolog EcoPlate untuk mempelajari diversitas katabolik komunitas bakteri tanah dengan variasi spasial yaitu daerah restorasi, daerah tidak ditanami dan daerah pertanian serta tiga kedalaman tanah yang berbeda $(0-10 \mathrm{~cm}, 20-$ $30 \mathrm{~cm}$, dan $40-50 \mathrm{~cm}$ ). Hasil penelitian tersebut menunjukkan bahwa penggunaan substrat karbon pada kedalaman tanah 0-10 cm memiliki kesamaan untuk ketiga variasi lokasi. Pada kedalaman 20-30 $\mathrm{cm}$ dan 40-50 cm profil katabolik pada perlakuan restorasi dan tidak ditanami mengelompok menjadi dua kelompok, sedangkan untuk perlakuan daerah pertanian polanya tersebar.

Lapisan tanah yang menutupi permukaan akar tanaman yang masih dipengaruhi oleh aktivitas akar dikenal sebagai daerah rhizosfer. Pada daerah inilah umumnya akar tanaman berinteraksi dengan bakteri (Hardoim et al., 2008). Bakteri rhizosfer

dapat masuk ke dalam jaringan tanaman membentuk bakteri endofit melalui rambut akar, zona pemanjangan, ujung akar atau pada titik munculnya akar sekunder. Komunitas mikroba yang berasosiasi dengan perakaran tanaman tidak terdistribusi dengan seragam di seluruh daerah perakaran baik di dalam jaringan sebagai endofit maupun di daerah rhizosfer. Komunitas mikroba dapat berubah secara temporal ataupun spasial. Variasi pada struktur komunitas mikroba dapat mempengaruhi proses-proses pada ekosistem. Untuk memahami peranan komunitas bakteri yang berasosiasi dengan umbi ubi jalar maka penting untuk mengetahui diversitas fungsional dari komunitas mikroorganismenya. Analisis communitylevel physiological profiling (CLPP) merupakan pendekatan yang dapat diaplikasikan dalam mempelajari karakteristik dari komunitas mikroba. Metode ini berdasarkan pada penggunaan sumber karbon berbeda oleh mikroba. Pendekatan ini dilakukan dengan inokulasi langsung sampel dari lingkungan ke microplate dan keuntungan dari respons hasilnya dapat menjelaskan perbedaan dalam komunitas mikroba yang tampak dengan perkembangan warna yang menunjukkan variasi dalam diversitas atau pola warna yang terjadi (Garland, 1997). Pendekatan ini mencerminkan aktivitas langsung dan memberikan informasi fisiologis pada pola komunitas dalam pemanfaatan substrat. Penelitian ini bertujuan untuk mengetahui kelimpahan dan aktivitas metabolik mikroorganisme yang berasosiasi dengan akar dari ubi jalar baik sebagai endofit maupun rhizosfer.

\section{Material dan Metode Penelitian \\ Analisis Profil Fisiologi Tingkat Komunitas (Community-level physiological profiling/CLPP)}

Sampel yang digunakan dalam penelitian ini adalah tanah dan akar tanaman ubi jalar varietas cilembu. Analisis CLPP dilakukan untuk setiap sampel endofit dan rhizosfer dengan menggunakan BiologTM EcoPlates (Biolog, Inc., Hayward, California, USA). Sebanyak 10 gram tanah rhizosfer dimasukkan ke dalam $90 \mathrm{~mL}$ Phosphate Buffer Saline (PBS) steril hingga diperoleh pengenceran 101. Sebanyak $1 \mathrm{~mL}$ suspensi dari pengenceran 10-1 dimasukkan ke dalam $9 \mathrm{~mL}$ PBS hingga diperoleh pengenceran $10^{-2}$, dilakukan sampai pengenceran $10^{-3}$. Suspensi dari pengenceran $10^{-3}$ diinokulasikan sebanyak 150 uL ke dalam setiap sumur pada Ecoplate. Analisis CLPP untuk endofit dilakukan dengan memasukkan 10 gram sampel yang telah disterilisasi permukaan ke dalam $90 \mathrm{~mL}$ PBS dan dilakukan pengenceran berseri. Suspensi dari pengenceran $10^{-2}$ diinokulasikan sebanyak $150 \mathrm{uL}$ ke dalam setiap sumur pada Ecoplate. Selanjutnya Ecoplate diinkubasi pada suhu ruang dan konsidi gelap selama 120 jam (Classen et al., 2006).

\section{Analisis Data}

Pengukuran absorbansi EcoPlate dilakukan setiap 12 jam dengan microplate reader pada panjang gelombang 590 dan $750 \mathrm{~nm}$. Nilai optical 
density (OD) akhir yang digunakan adalah nilai OD pada pembacaan 590 (pembentukan warna dan turbiditas) dikurangi pembacaan pada $750 \mathrm{~nm}$ (turbiditas saja) setelah dikoreksi terhadap nilai absorbansi pada sumur kontrol (blanko/A1). Nilai OD negatif atau kurang dari 0,06 diset menjadi nol (Classen et al., 2006).

Total aktivitas metabolik populasi mikroorganisme ditunjukkan dengan Average Well Color Development (AWCD). Nilai AWCD dihitung dengan rumus: $A W C D=\Sigma(C-R) / 31$, dengan $\mathrm{C}=$ absorbansi pada sumur yang mengandung sumber karbon, R=absorbansi pada sumur kontrol. Analisis dilakukan berdasarkan penggunaan dari seluruh individu substrat dan penggunaan kelompok substrat (karbohidrat, asam karboksilat, asam amino, amina dan amida, polimer, dan senyawa fenolik). Nilai indeks keanekaragaman dihitung dengan rumus: $\mathrm{H}=\Sigma(\mathrm{Pi} \quad \mathrm{x} \operatorname{lnPi})$ dengan $\mathrm{Pi}$ merupakan proporsi nilai OD akhir untuk setiap sumur. Nilai indeks kemerataan dihitung dengan rumus: $\mathrm{E}=\mathrm{H} / \mathrm{InS}$, dengan $\mathrm{S}$ merupakan substrate richness, yaitu jumlah sumber karbon yang digunakan oleh komunitas mikroba (Deng et al., 2011).

\section{Hasil dan Pembahasan}

Analisis total aktivitas metabolik mikroba dinyatakan dalam AWCD (Average Well Color Development) yang menunjukkan laju pengunaan substrat atau rata-rata pembentukkan warna dari tiap sumur pada BiologTM EcoPlate. Laju penggunaan substrat dari komunitas mikroba pada rhizosfer $(0,013-0,57)$ lebih tinggi dibandingkan dengan mikroba endofit (0-0,51) (Gambar 1). Selanjutnya, waktu yang dibutuhkan untuk menginisiasi aktivitas enzimatik oleh mikroorganisme endofit (24-36 jam) lebih lama dibandingkan mikroorganisme rizofir (0-12 jam). Nilai AWCD naik secara lambat pada 24 jam pertama dan selanjutnya meningkat dengan cepat dan mencapai nilai absorbansi maksimum pada masa inkubasi 120 jam. Hasil ini menunjukkan bahwa aktivitas metabolik dan potensi penggunaan dari sumber karbon yang berbeda pada mikroorganisme rhizosfer lebih tinggi dibandingkan endofit.

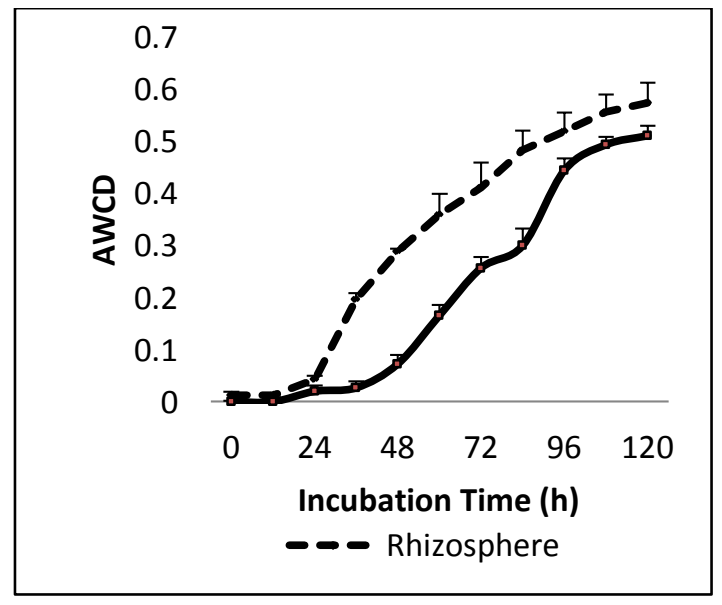

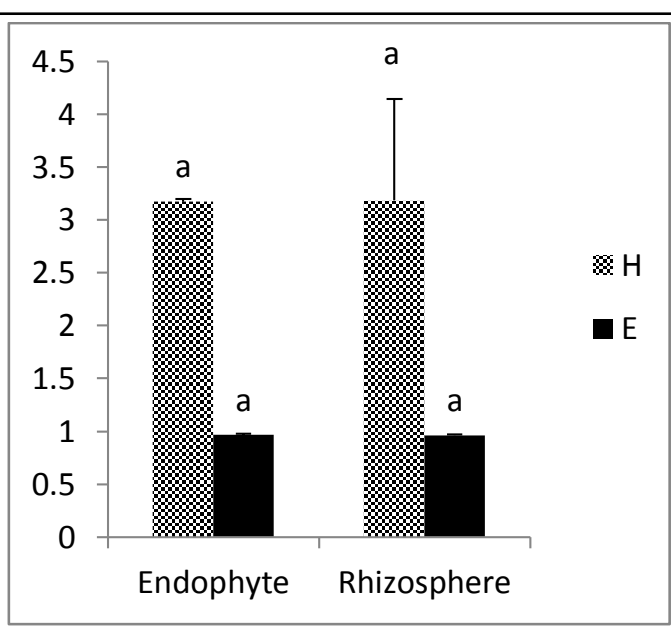

Gambar 1. Total aktivitas metabolik mikroorganisme yang terkait dengan akar (endofit dan rhizosfer) yang dinyatakan sebagai average well color development (AWCD) pada ubi jalar (Kiri). Nilai indeks Shannon $(\mathrm{H})$ dan Evenness $(\mathrm{E})$ substrat yang digunakan pada BiologTM Ecoplate (Kanan).

Berdasarkan pada Gambar 1, nilai indeks keanekaragaman $(\mathrm{H})$ dan kemerataan (E) penggunaan substrat dari komunitas endofit dan rhizosfer tidak berbeda nyata $(P<0.05)$. Hal ini menunjukkan rata-rata substrat yang digunakan oleh komunitas mikroba tidak berbeda antara endofit $(3,17 \pm 0,97)$ dan rhizosfer $(3,18 \pm 0,96)$. Nilai indeks kemerataan (E) menunjukkan bahwa tingkat aktivitas katabolisme terhadap 31 karbon relatif seragam namun tidak mempertimbangkan jenis sumber karbon yang digunakan.

Analisis profil fisiologi komunitas mikroba merupakan karakterisasi pola sidik jari metabolik dari komunitas mikroba yang merupakan pendekatan untuk mempelajari karakterisasi komunitas mikroba dengan membedakan kapabilitas metabolik dan diversitas fungsional komunitas mikroba. Biolog TM EcoPlate merupakan teknik untuk mempelajari profil fisiologi komunitas mikroba berdasarkan penggunaan substrat. EcoPlate terdiri dari 31 jenis substrat karbon yang terbagi dalam kelompok substrat karbohidrat, polimer, asam karboksilat, asam amino, amina/amida, dan senyawa fenolik.

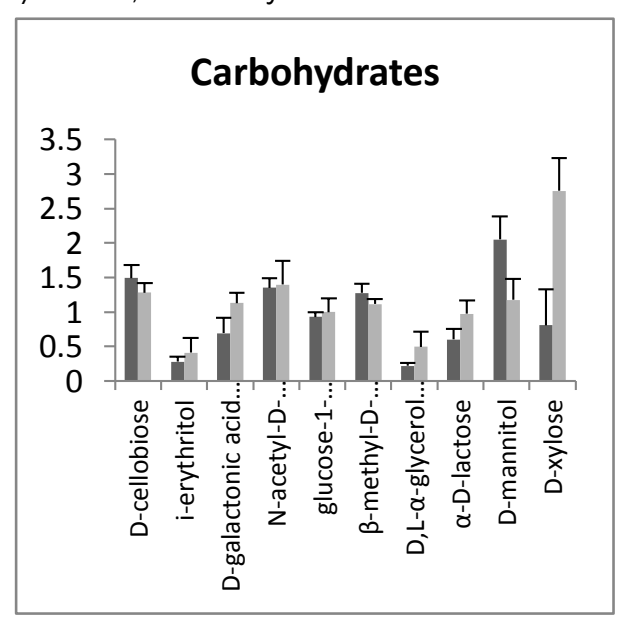

a 


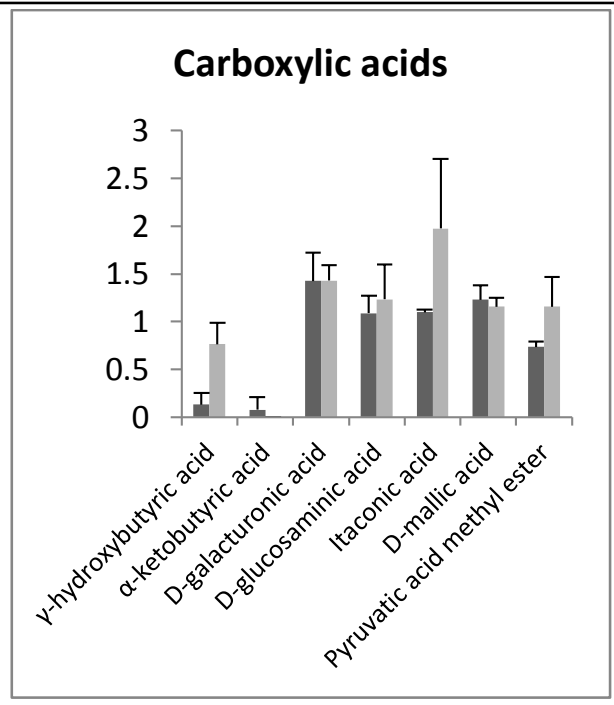

b.

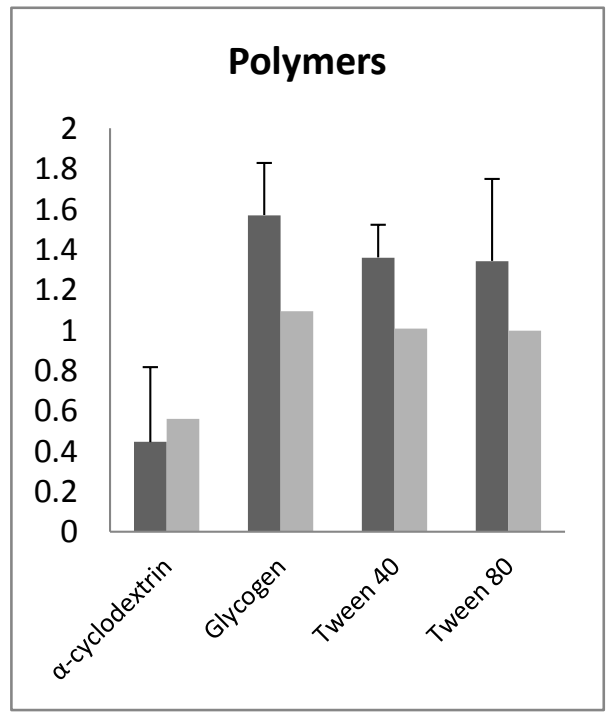

C

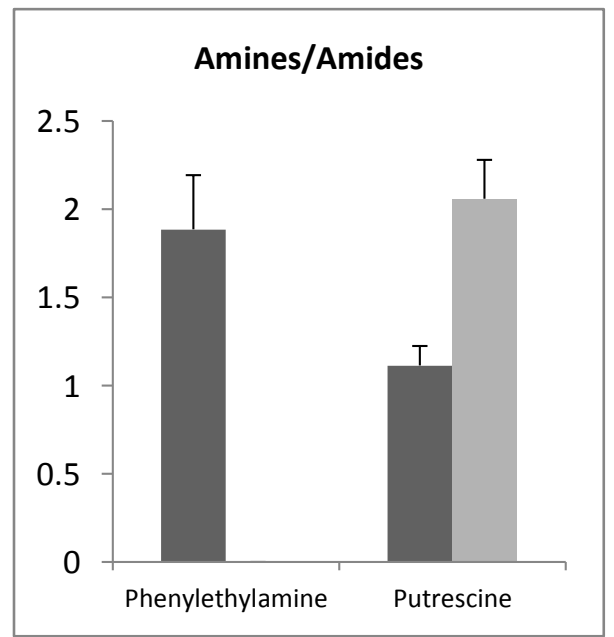

d

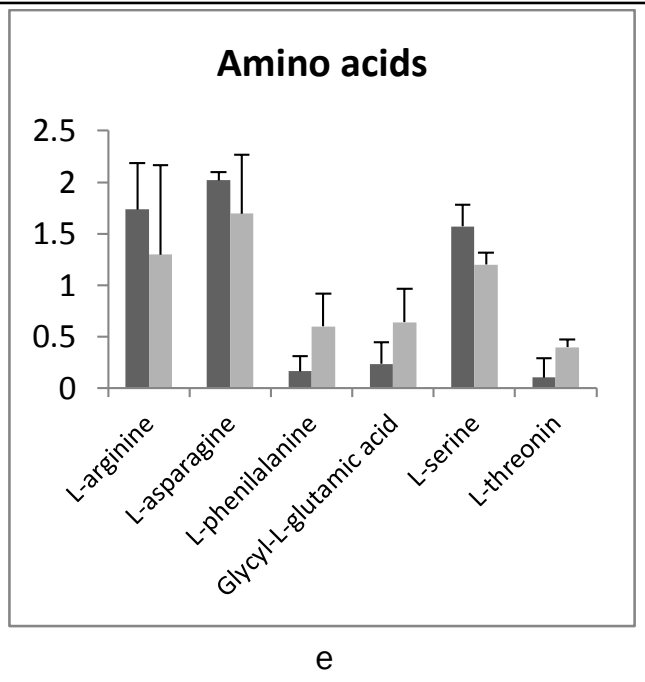

\section{Phenolic compounds}

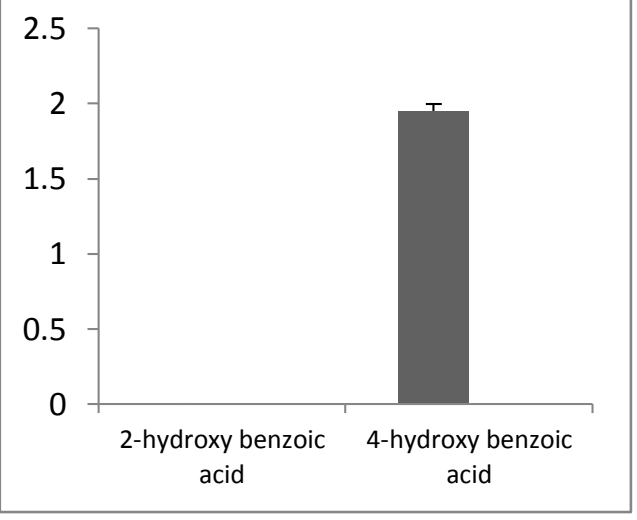

$f$

Gambar 2 (a,b,c,d,e,f). Grafik penggunaan substrat oleh komunitas endofit dan rhizosfer.

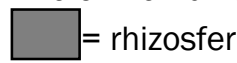

\section{endofit}

Analisis CLPP untuk penggunaan seluruh individu substrat dapat dilihat pada Gambar 2. Komunitas mikroba rhizosfer dapat menggunakan 30 sumber karbon dari total 31 sumber karbon. Satu sumber karbon dari kelompok senyawa fenolik yaitu 2-hydroxy benzoic acid tidak digunakan, sedangkan untuk komunitas mikroba endofit, dari total 31 sumber karbon, dapat menggunakan 27 sumber karbon. Empat subsrat yang tidak digunakan oleh mikroba endofit adalah $\alpha$ ketobutyric acid (asam karboksilat), phenylethylamine (amina/amida), 2-hydroxy benzoic acid dan 4-hydroxy benzoic acid (senyawa fenolik).

Secara umum penggunaan subsrat individu oleh komunitas mikroba rhizosfer dan endofit lebih tinggi pada kelompok karbohidrat. Mikroba endofit dengan penggunaan substrat tertinggi pada D-xylose $(2,75 \pm 0,4763)$ sedangkan mikroba rhizosfer pada substrat D-mannitol $(2,05 \pm 0,3345)$. karbohidrat yang digunakan sebagai sumber karbon dalam Biolog-EcoPlate sebagian besar merupakan derivat 
dari senyawa penyusun dinding sel tanaman. Penggunaan D-cellobiose melibatkan enzim selobiose, penggunaan D-galactonic acid $\mathrm{y}$-lactone melibatkan enzim D-galaktono- $\gamma$-laktonase, penggunaan $\beta$-methyl-D-glucoside melibatkan enzim $\beta$-D-glukosida glukohidrolase dan $\beta$-glukosidase, penggunaan $D, L-\alpha$-glycerol phosphate melibatkan enzim gliserol-3-fosfatase, penggunaan D-xylose melibatkan enzim xilosa melibatkan enzim xilosa isomerase dan xilub kinase (Caspi et al., 2014).

Penggunaan asam karboksilat pada oleh komunitas mikroba tidak berbeda, kecuali $\alpha$ ketobutyric acid yang tidak digunakan oleh mikroba endofit. Asam karboksilat bersama-sama dengan amonia merupakan hasil degradasi dari asam amino. Substrat D-glucosaminic acid, Itaconic acid, D-galacturonic acid dan D-mallic acid merupakan susbstrat yang dari kelompok asam karboksilat yang digunakan dengan baik oleh kedua komunitas mikroba dengan nilai rata-rata diatas 1 . Substrat Dglucosaminic acid merupakan komponen dari lipopolisakarida dinding sel bakteri (Pezzotti et al., 2005). Penggunaan substrat ini melibatkan enzim D-glucosaminic acid dehidratase. Mikroba yang dikenal memiliki enzim D-glucosaminic acid dehidratase adalah Pseudomonas fluorescens dan Agrobacterium radiobacter (Caspi et al., 2014). Dmalic acid (asam malat) merupakan salah satu komponen eksudat akar. sekresi asam malat oleh akar tanaman pisang menarik Bacillus amyloliquefaciens untuk membentuk biofilm pada permukaan akar sehingga mampu meningkatkan pertahanan tanaman pisang terhadap serangan patogen (Yuan et al., 2015).

Penggunaan substrat kelompok amina/amida, dari kedua komunitas menggunakan dengan baik substrat putrescine. Substrat putrescine merupakan senyawa poliamin bermuatan positif yang terdapat pada semua makhluk hidup yang berfungsi dalam pengikatan asam nukleat, stabilisasi membran dan stimulasi enzim sehingga dioerlukan untuk pertumbuhan yang optimal. Penggunaan asam amino L-arginine, L-asparagin dan L-serin digunakan dengan baik oleh kedua komunitas mikroba. Penggunaan asam amino L-arginine melibatkan arginase, ornitin aminotransferase dan arginin suksiniltransferase. Penggunaan L-asparagine melibatkan enzim asparaginase. Penggunaan Lserin mellibatkan enzim L-serin ammonia-liase, serta deaminase, L-serin deaminase dan L-serin dehidratase (Caspi et al., 2014).

\section{Kesimpulan}

Aktivitas total mikroba komunitas mikroba rhizosfer lebih tinggi dibandingkan dengan komunitas mikroba endofit. Analisis CLPP menunjukkan bahwa bakteri endofit dan rhizsofer ubi jalar dapat memanfaatkan semua kelompok sumber karbon sebagai berikut karbohidrat, asam amino, asam karboksilat, polimer, amina/amida, dan senyawa fenolik. Karbohidrat yang paling dimanfaatkan, pada mikroba endofit yaitu D-xylose
$(2,75 \pm 0,4763)$, sedangkan mikroba rhizosfer pada substrat D-mannitol $(2,05 \pm 0,3345)$.

\section{Daftar Pustaka}

Caspi, R., Altman, T., Billington, R., Dreher, K., Foesrster, H., Fulcher, C.A., Holand, T.A., Keseler, I.M., Kothari, A., Kubo, A., Krummenacker, M., Latendresse, M., Mueller, L.A., Ong, Q., Paley, S., Subhraveti, P., Weaver, D.S., Weerasinghe, D., Zang, P., dan Karp., P.D. The MetaCyc database of metabolic pathways and enzymes and the BioCyc collection of Pathway/Genome Databases. Nucleic Acid Research. 2014, 42, 459-471.

Classen, A.T., Boyle, S.I., Haskins, K.E., Overby, S.T., dan Hart, S.C. Community-level physiological profiles of bacteria and fungi: plate type and incubation temperature influences on contrasting soils. FEMS Microbiology Ecology. 2006, 44, 319-328.

Deng, H., Ge, L., Xu, T., Zhang, M., Wang, X., Zhang, Y., dan Peng, H. Analysis of the Metabolic Utilization of Carbon Sources and Potential Functional Diversity of the Bacterial Community in Lab-Scale Horizontal Subsurface-Flow Constructed Wetlands. J. Environ.Qual. 2011, 40, 1730-1736.

Garland, J.L. Analysis and interpretation of community-level profiles in microbial ecology, FEMS Microbiology Ecology. 1997, 24, 289300.

Hardoim, P.R., van Overbeek, L.S., dan van Elsas, J.D. Properties of bacterial endophytes and their proposed role in plant growth, Trends in Microbiology. 2008, 16, 463-471.

Konopka, A. What is microbial community ecology, The International Society for Microbial Ecology. 2009, 3, 1223 - 1230.

Pezzotti., F., Therisod, H., dan Therisod, M. Enzymatic synthesis of D-glucosaminic acid from D-glucosamine, Carbohydrate Research. 2005, 340, 139-141.

Wang, G. H., Jin, J., Chen, X. L., Liu, J. D., Liu., X. B., dan Herbert, S. J. Biomass and catabolic diversity of microbial communities with longterm restoration, bare fallow and cropping history in Chinese Mollisols, Plant, Soil and Environment. 2007, 53, 177 - 185.

Yuan, J., Zhang, N., Huang, Q., Raza, W., Li, R., Vivanco, J.M., dan Shen, Q. Organic acids from root exudates of banana help root colonization of PGPR strain Bacillus amyloliquefaciens NJN6, Scientific Reports. 2015, 5. 